that he shot himself in the Smithsonian's off-site storage facility.

The public-facing aspects of museum jobs are often a draw for applicants. "You can do research and teaching at universities, but at the museums, you can also share what you think is exciting with the general public, through exhibitions," says Manabe. Studies suggest that many people learn about science topics such as climate change not so much in the classroom, but in informal environments such as museums and zoos ${ }^{5,6}$.

Museum scientists also work with nonscientists more often than do many other types of researcher. For example, designing exhibitions might involve working with artists and educators. "You have to be a team player, and recognize the expertise that other people have," says Bettison-Varga.

Museum visitors love the chance to speak directly with scientists, says Molly Porter, school-programmes manager at the Natural History Museum of Los Angeles County. For example, she organizes workshops for teachers. The goal, she tells the scientists who take part, is to make their work accessible and relevant.

\section{COLLECTIVE EXPERIENCE}

Scientists chasing museum jobs must have $\mathrm{CVs}$ that demonstrate relevant experience. For top-level curator and researcher positions, high-quality science and a $\mathrm{PhD}$ are crucial. Experience with collections is also important. One path towards such experience is to select a graduate programme with a museum affiliation, suggests BettisonVarga. A university might have links with a museum, or it might have its own collections.

Museums also look for people who've worked in informal learning environments, says Perry Roth-Johnson, an exhibit researcher in air and space at the California Science Center in Los Angeles. Researchers can pick up required skills by volunteering or interning at a museum. Scientists can offer to write materials, give a lecture or run a hands-on workshop with the museum. Researchers might also sign on to mentor students through the museum's networks.

Persistence can pay off, too. Palaeontologist Ghazala Roohi first applied to the Pakistan Museum of Natural History in Islamabad in 1984, after earning her master's degree. She wasn't hired, so six months later she obtained a volunteer research-associate position. Two years later - after joining a joint expedition with the Pakistan museum and a visiting team from Harvard University's Peabody Museum of Archaeology and Ethnology in Cambridge, Massachusetts - she won a permanent salaried job at the museum. She earned a PhD in 2013 and now directs the Earth-sciences division.

Scientists need not find a full-time museum position to work with collections.

Researchers can often visit to do so, as Roohi did while she worked on her $\mathrm{PhD}$. She spent time at seven museums to study fossils of rhinoceros and of Baluchitherium, the largest land mammal ever to walk Earth ${ }^{7,8}$

Another way to access collections is to become an associate researcher. Chemical biologist Mandë Holford earns her salary at Hunter College in New York City, but she is also affiliated with the nearby American Museum of Natural History, and so can access lab space and the museum's collections.

The museum doesn't tend to advertise associate positions, she says. But she got in touch and, on the basis of her CV and publication record, the curators voted that her work would contribute to the museum's interests. "It's a way for the museum to expand its scientific reach and its staff," says Holford. Today, with a foot in research both at a university and in a museum, she can help students from either place to find opportunities and internships. She has also given presentations and mentored students who came to her lab as a result of her museum connections. "You get to reach out to the public in ways that you can't do as a traditional university faculty," says Holford. Because no one else there studies molluscs, she works

"We think about what we have, and we think about what five generations of scientists after us are going to do with it." with a collection manager to maintain the mollusc cabinets.

Scientists who work in museums report high levels of satisfaction. "If it's right for you, then it's deeply fulfilling," says Johnson - who feels that way about her job even when she's elbow-deep in koala guts, gathering their organs to determine which genes are expressed where.

Many of her former colleagues, she notes, stick around after they retire, enjoying their research while freed from the burden of administrative tasks. "They literally retire and come back to work the following Monday," she says. "How lucky that we get to work in something that doesn't even feel like a job."

Amber Dance is a freelance writer in Los Angeles, California.

1. Rayner, M. J., Taylor, G. A., Gaskin, C. P. \& Dunphy, B. J. Emu 117, 290-298 (2017)

2. Kemp, C. Nature 518, 292-294 (2015).

3. Jungblut, A. D. \& Hawes, I. Proc. R. Soc. B 284, 20170833 (2017).

4. Slater, G. J., Goldbogen, J. A. \& Pyenson, N. D. Proc. R. Soc. B 284, 20170546.

5. Falk, J. H. \& Dierking, L. D. Am. Sci. 98, 486-493 (2010).

6. Clayton, S. in Oxford Research Encyclopedia of Climate Science (ed. von Storch, H.) (Oxford Univ. Press, 2017).

7. Roohi, G., Raza, S. M., Khan, A. M., Ahmad, R. R. \& Akhtar, M. Pak. J. Zool. 47, 1433-1443 (2015).

8. Antoine, P.-O. et al. Zool. J. Linn. Soc. 160 139-194 (2010).

\section{IMMIGRATION}

\section{EU workers eye the exit}

Brexit, the withdrawal of the United Kingdom from the European Union, continues to foster anxiety among European nationals who work in Britain as scientists and in related occupations, a study finds.

A membership survey by Prospect, a London-based trade union whose members include 141,000 scientists and engineers, found that nearly $70 \%$ of the 650 respondents who are European nationals are considering leaving the United Kingdom. About half of those respondents work in science, technology, engineering and mathematics.

The numbers echo findings from a January survey of 1,000 UK-based university faculty and staff members. That study, conducted by the University and College Union, which represents UK higher-institution employees, found that $76 \%$ of respondents who were EU nationals were considering leaving the United Kingdom in the wake of Brexit.

The Prospect study reveals ongoing concerns about the free movement of highly skilled workers and uncertainty about how the government will address migration issues.

\section{RESEARCH}

\section{US federal funding rises}

US federal funding of academic research and development (R\&D) increased between 2015 and 2016 for the first time since 2010, according to data from the US National Science Foundation (NSF).

When adjusted for inflation, federal funding for academic $\mathrm{R} \& \mathrm{D}$ rose by $1.4 \%$ during that period, former President Barack Obama's last year in office, the data show. The NSF examined 640 US institutions that reported at least US\$1 million in R\&D outlays during their previous fiscal year.

Universities reported increases in research funding from all major federal agencies except the NSF. Research funded by NASA and the Departments of Agriculture, Defense, Energy and Health and Human Services - of which the US National Institutes of Health is part - rose between about $2 \%$ and $8 \%$ over 2015.

Research funded by nonprofit organizations soared by $9.4 \%$ to $\$ 4.6$ billion. Nonfederal funding from other national or federal governments, other universities or from donations also surged, rising nearly $9 \%$ to $\$ 2.2$ billion in 2016 . 